\title{
Picophytoplankton biomass distribution in the global ocean
}

\author{
E. T. Buitenhuis ${ }^{1}$, W. K. W. Li $^{2}$, D. Vaulot ${ }^{3}$, M. W. Lomas ${ }^{4}$, M. R. Landry ${ }^{5}$, F. Partensky ${ }^{3}$, D. M. Karl ${ }^{6}$,

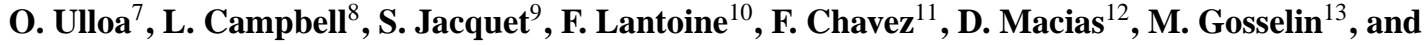 \\ G. B. McManus ${ }^{14}$ \\ ${ }^{1}$ Tyndall Centre for Climate Change Research and School of Environmental Sciences, University of East \\ Anglia, Norwich NR4 7TJ, UK \\ ${ }^{2}$ Fisheries and Oceans Canada, Bedford Institute of Oceanography, Dartmouth, Nova Scotia, Canada \\ ${ }^{3}$ CNRS and UPMC, Paris 06, UMR7144, Station Biologique, 29680 Roscoff, France \\ ${ }^{4}$ Bermuda Institute of Ocean Sciences, St. George's GE01, Bermuda, USA \\ ${ }^{5}$ Scripps Institution of Oceanography, University of California San Diego, La Jolla, California, USA \\ ${ }^{6}$ Department of Oceanography, University of Hawaii, Honolulu, HI 96822, USA \\ ${ }^{7}$ Department of Oceanography, University of Concepción, Casilla 160-C, Concepción, Chile \\ ${ }^{8}$ Department of Oceanography, Texas A\&M University, College Station, TX 77843, USA \\ ${ }^{9}$ INRA, UMR CARRTEL, 75 Avenue de Corzent, 74200 Thonon-les-Bains, France \\ ${ }^{10}$ UPMC Univ Paris 06, CNRS, LECOB, Observatoire Océanologique, 66650, Banyuls/Mer, France \\ ${ }^{11}$ MBARI, 7700 Sandholdt Rd, Moss Landing, CA 95039, USA \\ ${ }^{12}$ Department of Coastal Ecology and Management, Instituto de Ciencias Marinas de Andalucía \\ (ICMAN-CSIC), Avd. Republica Saharaui s/n, CP11510, Puerto Real, Cádiz, Spain \\ ${ }^{13}$ Institut des sciences de la mer de Rimouski, Université du Québec à Rimouski, 310 Allée des Ursulines, \\ Rimouski, Québec G5L 3A1, Canada \\ ${ }^{14}$ Department of Marine Sciences, University of Connecticut, Groton, CT 06340, USA \\ Correspondence to: E. T. Buitenhuis (http://tinyurl.com/contacterik)
}

Received: 13 February 2012 - Published in Earth Syst. Sci. Data Discuss.: 27 April 2012

Revised: 5 July 2012 - Accepted: 14 August 2012 - Published: 29 August 2012

\begin{abstract}
The smallest marine phytoplankton, collectively termed picophytoplankton, have been routinely enumerated by flow cytometry since the late 1980s during cruises throughout most of the world ocean. We compiled a database of 40946 data points, with separate abundance entries for Prochlorococcus, Synechococcus and picoeukaryotes. We use average conversion factors for each of the three groups to convert the abundance data to carbon biomass. After gridding with $1^{\circ}$ spacing, the database covers $2.4 \%$ of the ocean surface area, with the best data coverage in the North Atlantic, the South Pacific and North Indian basins, and at least some data in all other basins. The average picophytoplankton biomass is $12 \pm 22 \mu \mathrm{g} \mathrm{Cl}^{-1}$ or $1.9 \mathrm{~g} \mathrm{C} \mathrm{m}^{-2}$. We estimate a total global picophytoplankton biomass of $0.53-1.32 \mathrm{Pg} \mathrm{C}(17-39 \%$ Prochlorococcus, $12-15 \%$ Synechococcus and 49-69\% picoeukaryotes), with an intermediate/best estimate of $0.74 \mathrm{Pg} \mathrm{C}$. Future efforts in this area of research should focus on reporting calibrated cell size and collecting data in undersampled regions.
\end{abstract}

http://doi.pangaea.de/10.1594/PANGAEA.777385 


\section{Introduction}

Picophytoplankton are usually defined as phytoplankton less than 2 or $3 \mu$ m diameter (e.g. Sieburth et al., 1978; Takahashi and Hori, 1984; Vaulot et al., 2008). They are the smallest class of phytoplankton and are composed of both prokaryotes and eukaryotes. The eukaryotes $(0.8-3 \mu \mathrm{m})$ are a taxonomically diverse group that includes representatives from four algal phyla: the Chlorophyta, Haptophyta, Cryptophyta and Heterokontophyta (Vaulot et al., 2008). The prokaryotes belong to the phylum cyanobacteria and are subdivided into the genera Prochlorococcus $(\sim 0.6 \mu \mathrm{m})$ and Synechococcus $(\sim 1 \mu \mathrm{m})$, with each group having many ecotypes that dominate in different ocean regions (Johnson et al., 2006).

Picophytoplankton tend to dominate the phytoplankton biomass under oligotrophic conditions such as in the subtropical gyres (Alvain et al., 2005), where their high surfaceto-volume ratio makes them the best competitors for low nutrient concentrations (Raven, 1998). The abundance of the prokaryotes is often inversely related with the eukaryotes, which are favoured by more physically active mixed layers (e.g. Boumann et al., 2011). Furthermore, with warming of the temperate to subpolar North Atlantic and the Canadian high Arctic, picophytoplankton (specifically picoeukaryotes) have been found to become an increasingly large fraction of the total chlorophyll (Li et al., 2009; Moran et al., 2010).

As part of the marine ecology data synthesis effort (MAREDAT, this special issue), we compiled a database on picophytoplankton in the global ocean. MAREDAT is a community effort to synthesise abundance and carbon biomass data for the major lower trophic level taxonomic groups in the marine ecosystem. It addresses both autotrophs and heterotrophs and covers the size range from bacteria to macrozooplankton.

\section{Data}

We compiled data for picophytoplankton abundance in three taxonomic groups: Prochlorococcus, Synechococcus, and picoeukaryotes (Table 1). We used the size range of picoeukaryotes as defined by the contributing researchers. The size range has a large impact on the resulting biomass (see Discussion). All of the data were obtained by flow cytometry. Both the raw data and the gridded data are available from PANGAEA (http://doi.pangaea.de/10.1594/ PANGAEA.777385) and the MAREDAT webpage (http:// maremip.uea.ac.uk/.maredat.html).

\subsection{Conversion factors}

Conversion factors from cell abundance to carbon biomass for the three picophytoplankton groups were compiled from the literature (Table 2). Conversion factors were either measured directly on unialgal cultures in the laboratory or derived from indirect methods on in situ samples. Most of the

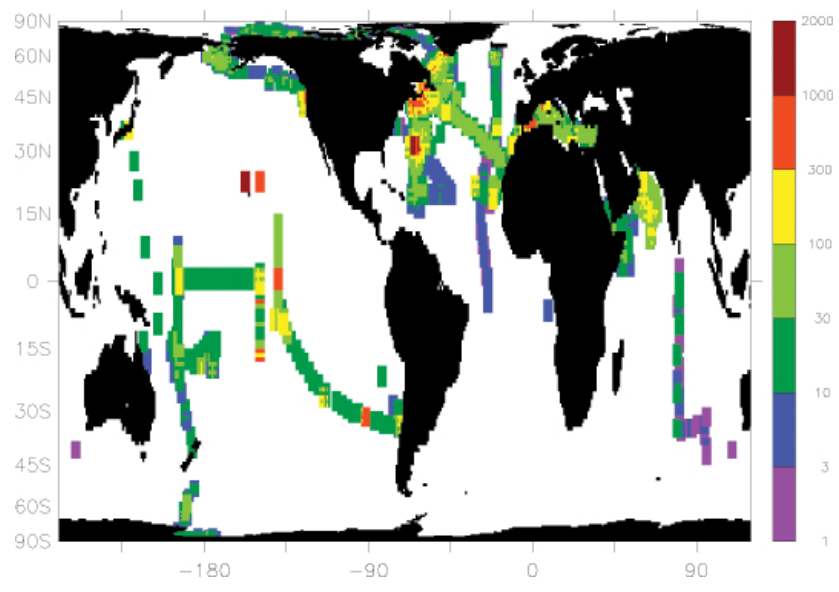

Figure 1. Horizontal distribution of the number of observations. Data points have been enlarged to $5^{\circ} \times 5^{\circ}$.

indirect measures were derived from cell sizes that were estimated from average forward-angle light scatter (FALS) multiplied by a carbon content per biovolume. The conversion factors of Veldhuis et al. (1997) were based on nitrate uptake in incubated in situ samples and assuming a $\mathrm{C}: \mathrm{N}$ ratio of 6 . Since the biggest source of variability in the other indirect measures is the carbon content per biovolume, which was measured on laboratory cultures, the advantage of using in situ biovolume to determine conversion factors does not seem to improve the local applicability of these data, and we therefore used the directly measured conversion factors as the standard.

\subsection{Quality control}

Contributed data were assumed to have undergone the contributing researchers' own internal quality control procedures. As a statistical filter for outliers, we applied the Chauvenet criterion (Buitenhuis et al., 2012b) to the total carbon data. The data were not normally distributed, so we logtransformed them, excluding zero values. No high outliers were found by this criterion. The highest picophytoplankton biomass in the database is $575 \mu \mathrm{g} \mathrm{Cl}^{-1}$, measured near the coast of Oman (Indian Ocean).

\section{Results}

The database contains 40946 data points (Fig. 1). Data are included from a number of stations that have been sampled repeatedly over many years or programs where measurements have been made on a fine-resolution grid. Therefore, after gridding, we obtained 10747 data points on the World Ocean Atlas grid $\left(1^{\circ} \times 1^{\circ} \times 33\right.$ vertical layers $\times 12$ months $)$, representing a coverage of vertically integrated and annually averaged biomass for $2.4 \%$ of the ocean surface. For further details on the gridding, see Buitenhuis et al. (2012b). To limit 
Table 1. Data sources.

\begin{tabular}{|c|c|c|c|}
\hline Cruise & Date & Area & Reference/Investigator \\
\hline Li87022 & Jun 1987 & North Atlantic & Li and Wood (1988); Li et al. (1992) \\
\hline CHLOMAX & Sep-Oct 1987 & Sargasso Sea & Neveux et al. (1989) \\
\hline Endeavour177 & May-Jun 1988 & Sargasso Sea & Olson et al. (1990) \\
\hline Li88026 & Sep 1988 & North Atlantic & Li et al. (1992) \\
\hline Bermuda & 1988-1989 & Sargasso Sea & Olson et al. (1990) \\
\hline EROSDISCO89 & Jan 1989 & Mediterranean Sea & Vaulot et al. (1990) \\
\hline Li89003 & Apr 1989 & North Atlantic & Li et al. (1992) \\
\hline Oceanus206 & May 1989 & Sargasso Sea & Olson et al. (1990) \\
\hline EROSBAN & Jul 1989 & Mediterranean Sea & Partensky (unpublished data) \\
\hline NIOZNatl89 & Aug-Sep 1989 & North Atlantic & Veldhuis and Kraay (1990); Veldhuis et al. (1993) \\
\hline Palau & Aug-Sep 1990 & Tropical Pacific West & Shimada et al. (1993) \\
\hline NOPACCS & Aug-Oct 1990 & Pacific Ocean & Ishizaka (unpublished data) \\
\hline Australia & Nov-Dec 1990 & Tropical Pacific West & Shimada et al. (1993) \\
\hline HOT & 1990-2008 & Tropical Pacific & Campbell et al. (1997); Karl (unpublished data) \\
\hline BATS & 1990-2010 & North Atlantic & DuRand et al. (2001); Lomas et al. (2010) \\
\hline Iselin 9102 & Feb 1991 & Carribean Sea & McManus and Dawson (1994) \\
\hline Li91001 & Apr 1991 & North Atlantic & $\mathrm{Li}$ (unpublished data) \\
\hline BOFS & Jul 1991 & North Atlantic & BODC (British Oceanographic Data Centre) \\
\hline POEM91 & Oct 1991 & Mediterranean Sea & Li et al. (1993) \\
\hline EUMELI3 & Oct 1991 & Tropical Atlantic & Partensky et al. (1996) \\
\hline EQPACTT007 & Feb-Mar 1992 & Equatorial Pacific & Landry et al. (1996) \\
\hline Eddy92 & Mar 1992 & Mediterranean Sea & Yacobi et al. (1995) \\
\hline EROSVALD & Mar 1992 & Mediterranean Sea & Vaulot, Marie (unpublished data) \\
\hline EQPACTT008 & Mar-Apr 1992 & Equatorial Pacific & Binder et al. (1996) \\
\hline EQPACTT008D & Mar-Apr 1992 & Equatorial Pacific & DuRand and Olson (1996) \\
\hline NIOZIndian & May 1992-Feb 1993 & Indian Ocean/Red Sea & Veldhuis and Kraay (1993) \\
\hline SurugaBay & May 1992-Oct 1993 & Japan & Shimada et al. (1995) \\
\hline EUMELI4 & Jun 1992 & Tropical Atlantic & Partensky et al. (1996) \\
\hline Surtropac17 & Aug 1992 & Equatorial Pacific & Blanchot and Rodier (1996) \\
\hline EQPACTT011 & Aug-Sep 1992 & Equatorial Pacific & Landry et al. (1996) \\
\hline Li92037 & Sep 1992 & North Atlantic & $\operatorname{Li}(1994,1995)$ \\
\hline EQPACTT012 & Sep-Oct 1992 & Equatorial Pacific & DuRand and Olson (1996) \\
\hline EUMELI5 & Dec 1992 & Tropical Atlantic & Partensky et al. (1996) \\
\hline Aquaba & 1992-1993 & Red Sea & Lindell and Post (1995) \\
\hline Malaga93 & Jan 1993 & Mediterranean Sea & Garcia et al. (1994) \\
\hline Li93002 & May 1993 & North Atlantic & $\operatorname{Li}(1994,1995)$ \\
\hline EROSDISCO93 & Jul 1993 & Mediterranean Sea & Simon, Barlow, Marie (unpublished data) \\
\hline NOAA93 & Jul-Aug 1993 & North Atlantic & Buck et al. (1996) \\
\hline Flupac & Sep-Oct 1994 & Equatorial Pacific & Blanchot et al. (2001) \\
\hline OLIPAC & Nov 1994 & Equatorial Pacific & Neveux et al. (1999) \\
\hline ArabianTTN043 & Jan 1995 & Arabian Sea & Campbell et al. (1998) \\
\hline ArabianTTN045 & Mar-Apr 1995 & Arabian Sea & Campbell et al. (1998) \\
\hline Delaware95 & Apr 1995 & North Atlantic & Li (1997) \\
\hline MINOS & Jun 1995 & Mediterranean Sea & Vaulot, Marie, Partensky (unpublished data) \\
\hline Chile95 & Jun 1995 & South Pacific & $\mathrm{Li}$ (unpublished data) \\
\hline Lopez96 & Jun 1995 & Sargasso Sea & $\mathrm{Li}$ (unpublished data) \\
\hline Li95016 & Jul 1995 & North Atlantic & Li and Harrison (2001) \\
\hline Ictio-Alborán Cadiz 95 & Jul 1995 & North Atlantic & Echevarría et al. (2009) \\
\hline ArabianTTN049 & Jul-Aug 1995 & Arabian Sea & Olson (unpublished data) \\
\hline ArabianTTN050 & Aug-Sep 1995 & Arabian Sea & Campbell et al. (1998) \\
\hline NOAA95 & Sep-Oct 1995 & Indian Ocean & Buck (unpublished data) \\
\hline ArabianTTN053 & Nov 1995 & Arabian Sea & Olson (unpublished data) \\
\hline ArabianTTN054 & Dec 1995 & Arabian Sea & Campbell et al. (1998) \\
\hline AZOMP & 1995-2009 & North Atlantic & Li (2002, 2009); Li et al. (2009) \\
\hline
\end{tabular}


Table 1. Continued.

\begin{tabular}{llll}
\hline Cruise & Date & Area & Reference/Investigator \\
\hline OMEX/D1221 & Jun 1996 & North Atlantic & BODC \\
AZMP & 1997-2009 & North Atlantic & Li (2002, 2009); Li et al. (2009) \\
Kiwi6 & Oct-Nov 1997 & Antarctica & Landry (unpublished data) \\
Kiwi7 & Dec 1997 & Antarctica & Landry (unpublished data) \\
Almo-1 & Dec 1997 & Mediterranean Sea & Jacquet, Marie (unpublished data) \\
AESOPS/NBP97-1 & 1997 & Ross Sea & Olson, Sosik (unpublished data) \\
Almo-2 & Jan 1998 & Mediterranean Sea & Jacquet et al. (2010) \\
Kiwi8 & Jan-Feb 1998 & Antarctica & Landry (unpublished data) \\
Kiwi9 & Feb-Mar 1998 & Antarctica & Landry (unpublished data) \\
Southwest Pacific & Mar-Apr 1998 & South Pacific & Campbell et al. (2005) \\
PROSOPE99 & Sept 1999 & Mediterranean Sea & Marie et al. (2006) \\
GLOBEC LTOP & Mar 2001-Sep 2003 & North Pacific & Sherr et al. (2005) \\
JOIS & 2002-2009 & North Atlantic, Arctic & Li (2002, 2009); Li et al. (2009) \\
NP & Feb 2004-Mar 2005 & North Atlantic & Lomas et al. (2009) \\
BIOSOPE & Oct-Dec 2004 & South East Pacific & Grob et al. (2007) \\
ArcticNet2005 & Aug-Sep 2005 & Arctic, North Atlantic & Tremblay et al. (2009) \\
DOP & May 2006-May 2008 & North Atlantic & Lomas (unpublished data) \\
C3O & 2007-2008 & North Atlantic, Arctic & Li (2002, 2009); Li et al. (2009) \\
Bering Sea & Mar 2008-May 2010 & North Pacific & Moran et al. (2012) \\
Line P & Aug 2010-Jun 2011 & North Pacific & Lomas (unpublished data) \\
FOODWEB & Feb-Aug 2011 & North Atlantic & Lomas (unpublished data) \\
\hline
\end{tabular}

Table 2. Cell abundance to carbon biomass conversion factors [ $\mathrm{fg} \mathrm{C} \mathrm{Cell}^{-1}$ ].

\begin{tabular}{|c|c|c|c|c|}
\hline & Prochlorococcus & Synechococcus & picoeukaryotes & reference \\
\hline \multirow{9}{*}{$\begin{array}{l}\text { Direct, from } \\
\text { cultures }\end{array}$} & & 250 & & Kana and Glibert (1987) \\
\hline & & 600 & $3800 \pm 100$ & Verity et al. (1992) \\
\hline & & & 800,1360 & Montagnes et al. (1994) \\
\hline & $49 \pm 9$ & & & Cailliau et al. (1996) \\
\hline & & $350(200-500)$ & & Liu et al. (1999) \\
\hline & & & 4400 & Llewellyn and Gibb (2000) \\
\hline & $27 \pm 6$ & & & Claustre et al. (2002) \\
\hline & $53 \pm 9$ & $170 \pm 65$ & & Bertilsson et al. (2003) \\
\hline & $16 \pm 1$ & $249 \pm 21$ & & Fu et al. (2007) \\
\hline average & 36 & $255^{*}$ & 2590 & \\
\hline \multirow{4}{*}{$\begin{array}{l}\text { Indirect, mostly } \\
\text { from culture } C \\
\text { per volume } \times \text { in } \\
\text { situ volume }\end{array}$} & 92 & 175 & & Veldhuis et al. (1997) \\
\hline & 53 & 246 & 2108 & Campbell et al. (1994) \\
\hline & 56 & 112 & & DuRand et al. (2001) \\
\hline & $39 \pm 1$ & $82 \pm 8$ & $530 \pm 185$ & Worden et al. (2004) \\
\hline average & 60 & 154 & 1319 & \\
\hline
\end{tabular}

${ }^{*}$ Excluding Verity et al. (1992), 324 fg C cell ${ }^{-1}$ including Verity et al. (1992). 


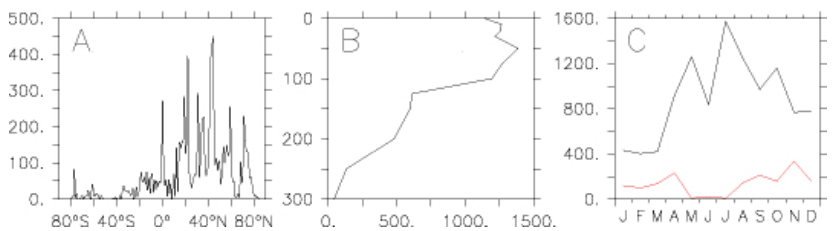

Figure 2. Number of grid points with data, as a function of (A) latitude. (B) Depth. Observations below $300 \mathrm{~m}$ are not shown $(1.4 \%$ of the data). The deepest observation is at $3000 \mathrm{~m}$ and the deepest nonzero observation at $1100 \mathrm{~m}$. (C) Time. Red: Southern Hemisphere, black: total.

the overrepresentation of well sampled locations, we present results of the gridded data. Only $15 \%$ of the data are from the Southern Hemisphere (Fig. 2a), $33 \%$ are from the tropics ( $43 \%$ of the ocean surface), while $13 \%$ are from the polar oceans ( $5 \%$ of the ocean surface). Observations in the upper $112.5 \mathrm{~m}$ make up $81 \%$ of the data (Fig. $2 \mathrm{~b}$ ), but the number of observations decreases more slowly than biomass (Fig. 3), and there are still 480 observations at $200 \mathrm{~m}$ depth (Fig. 2b), thus defining the vertical biomass profile fairly well. Zero values make up $1.6 \%$ of the data, and $95 \%$ of those are from below $62.5 \mathrm{~m}$ depth. There is some sampling bias towards the growing season, with $67 \%$ of the data sampled in the spring and summer months (Fig. 2c).

The average picophytoplankton biomass is $12 \pm 22 \mu \mathrm{g} \mathrm{Cl}^{-1}$ (Fig. 4) or $1.9 \mathrm{~g} \mathrm{C} \mathrm{m}^{-2}$. Of the vertically integrated biomass, $54 \%$ occurs in the upper $40 \mathrm{~m}$ and $93 \%$ in the upper $112.5 \mathrm{~m}$ (Fig. 2). Synechococcus is found at the most shallow depths (97\% above $112.5 \mathrm{~m}$, Fig. 5), followed by picoeukaryotes (92\% above $112.5 \mathrm{~m}$ ), while Prochlorococcus biomass decreases more slowly with depth ( $87 \%$ above $112.5 \mathrm{~m}$ ).

The average biomass is slightly higher in the tropics and considerably lower in the Arctic (Figs. 4, 6), but the standard deviation within latitudinal bands is high, so that none of the differences are significant. Antarctica: $11 \pm 8 \mu \mathrm{g} \mathrm{Cl}^{-1}$ or $1.2 \mathrm{~g} \mathrm{C} \mathrm{m}^{-2}$, south temperate zone $\left(67-23^{\circ} \mathrm{S}\right): 13 \pm 23 \mu \mathrm{g} \mathrm{Cl}^{-1}$ or $2.2 \mathrm{~g} \mathrm{C} \mathrm{m}^{-2}$, tropics: $15 \pm 24 \mu \mathrm{g} \mathrm{Cl}^{-1}$ or $2.2 \mathrm{~g} \mathrm{C} \mathrm{m}^{-2}$, north temperate zone: $12 \pm 22 \mu \mathrm{g} \mathrm{Cl}^{-1}$ or $1.9 \mathrm{~g} \mathrm{C} \mathrm{m}^{-2}$, and Arctic: $6 \pm 8 \mu \mathrm{g} \mathrm{Cl}^{-1}$ or $0.6 \mathrm{~g} \mathrm{C} \mathrm{m}^{-2}$. We calculate the global picophytoplankton biomass from the zonal and time-averaged concentration filled by interpolation across up to $22^{\circ}$ latitude (Fig. 6) multiplied by the volume at each latitude and depth, integrating to the bottom and counting missing values as 0 . We thus estimate a total global picophytoplankton biomass of $0.74 \mathrm{Pg} \mathrm{C}$ (17\% Prochlorococcus, $15 \%$ Synechococcus and $69 \%$ picoeukaryotes). Interpolation across up to $10^{\circ}$ latitude only leaves a few missing values and estimates $0.73 \mathrm{PgC}$. If we use the indirect in situ conversion factors for each of the three groups (Table 2), the total biomass (with up to $22^{\circ}$ interpolation) is $0.53 \mathrm{Pg} \mathrm{C}$ ( $39 \%$ Prochlorococcus, $12 \%$ Synechococcus, $49 \%$ picoeukaryotes).

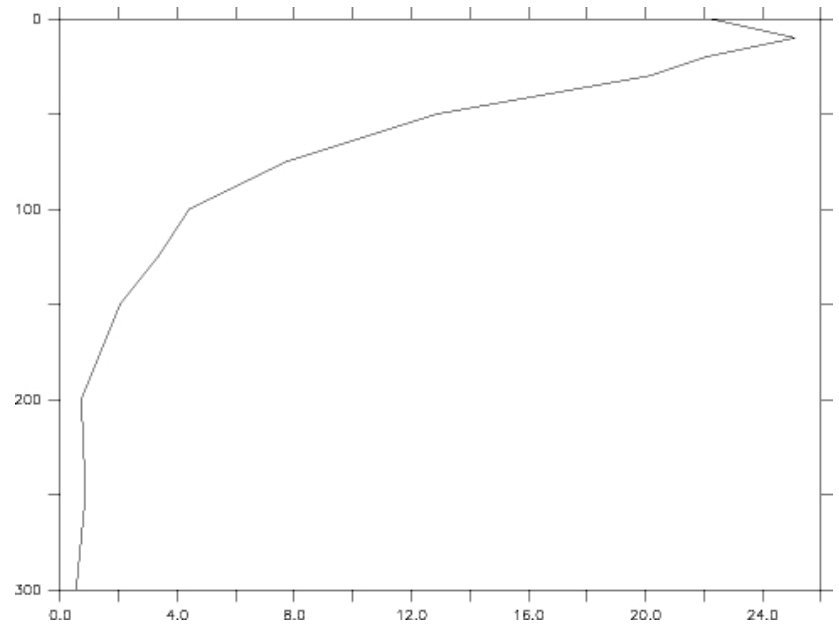

Figure 3. Average picophytoplankton biomass $\left[\mu \mathrm{C} \mathrm{Cl}^{-1}\right]$ as a function of depth $[\mathrm{m}]$.

Picoeukaryotes tend to dominate by $>75 \%$ poleward of $40^{\circ}$, and dominate below $62.5 \mathrm{~m}$ depth in the tropics and below $225 \mathrm{~m}$ everywhere (Fig. 7). Prochlorococcus tends to dominate above $225 \mathrm{~m}$ between $20-40^{\circ} \mathrm{N}$ and shares dominance with picoeukaryotes between $10-30^{\circ} \mathrm{S}$ and at the surface in the tropics. Synechococcus only dominates around $50^{\circ} \mathrm{S}$ and is relatively abundant above $62.5 \mathrm{~m}$ between 10 $40^{\circ} \mathrm{N}$. This is consistent with the community structure of picophytoplankton that has been analysed by Bouman et al. (2011).

\section{Discussion}

Although data coverage, at $2.4 \%$ of the ocean surface, is by no means complete, if we randomly select half of the depth profiles in 10 random samples, the average integrated biomass varies between 96 and $104 \%$ of the value for the whole dataset, while the averages from the Southern and Northern Hemispheres are $119 \%$ and $96 \%$, respectively. On the other hand, the average using the indirect in situ conversion factors is $72 \%$ of the value estimated using the direct conversion factors. Thus, the main uncertainty in determining the global picophytoplankton biomass in this analysis is the conversion from cell abundance to carbon biomass. There is a fairly tight relationship between forward-angle light scatter (FALS; Cavender-Bares et al., 2001; DuRand et al., 2002) or right-angle light scatter (RALS; Simon et al., 1994; Worden et al., 2004), as measured by flow cytometry, and cell size, which is probably the main source of uncertainty in the conversion factor. Only about a third of our data came with FALS or RALS data, and even in those cases these were in arbitrary units. We recommend the routine measurement of calibrated size as the additional measurement that would do most to improve our knowledge of global picophytoplankton biomass distribution. 


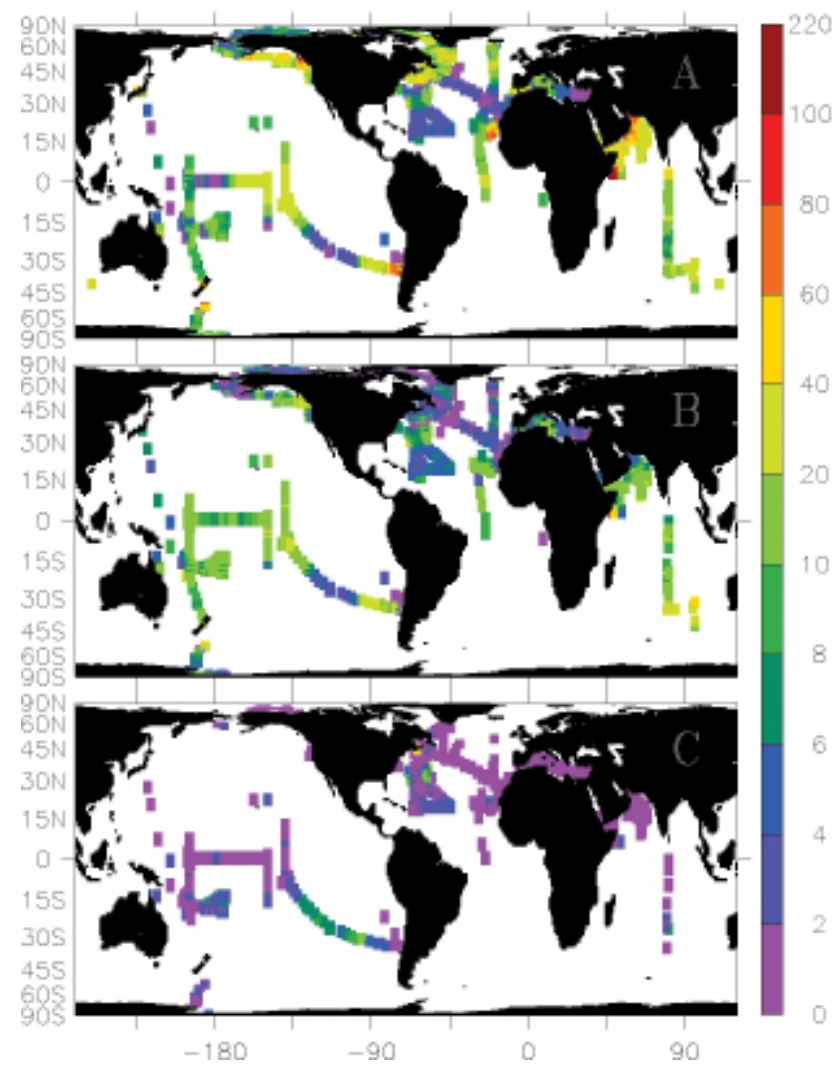

Figure 4. Picophytoplankton biomass $\left[\mu \mathrm{g} \mathrm{Cl} l^{-1}\right]$. (A) $0-40 \mathrm{~m}$, (B) $40-112.5 \mathrm{~m}$, (C) $112.5-225 \mathrm{~m}$.

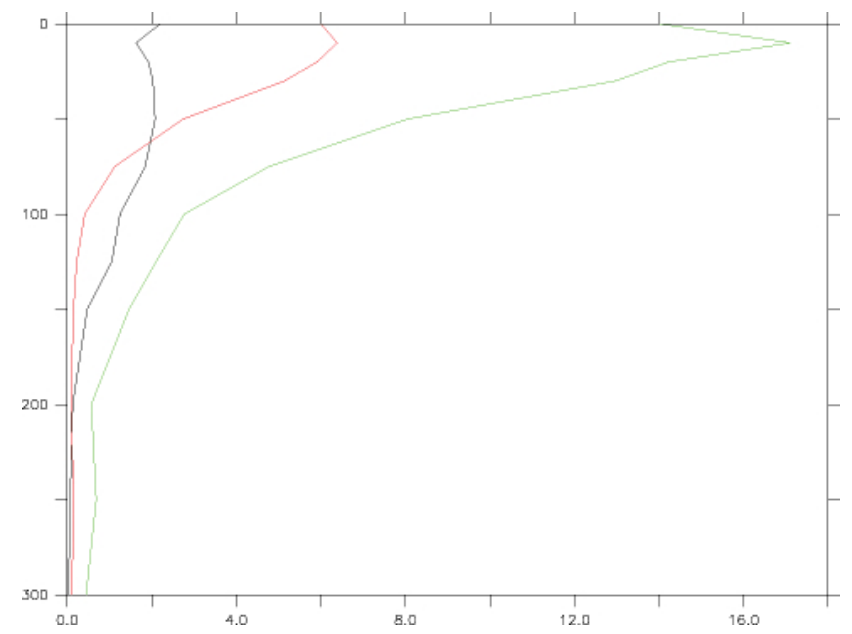

Figure 5. Average depth profiles of Prochlorococcus (black), Synechococcus (red) and picoeukaryotes (green) biomass $\left[\mu \mathrm{g} \mathrm{Cl}^{-1}\right]$.

In addition to the uncertainty in the carbon conversion factor, there is uncertainty about the abundance of Prochlorococcus in near-surface oligotrophic waters, where the cellular chlorophyll content, and thus the ability to detect them as algae from their red fluorescence, is at its minimum and near

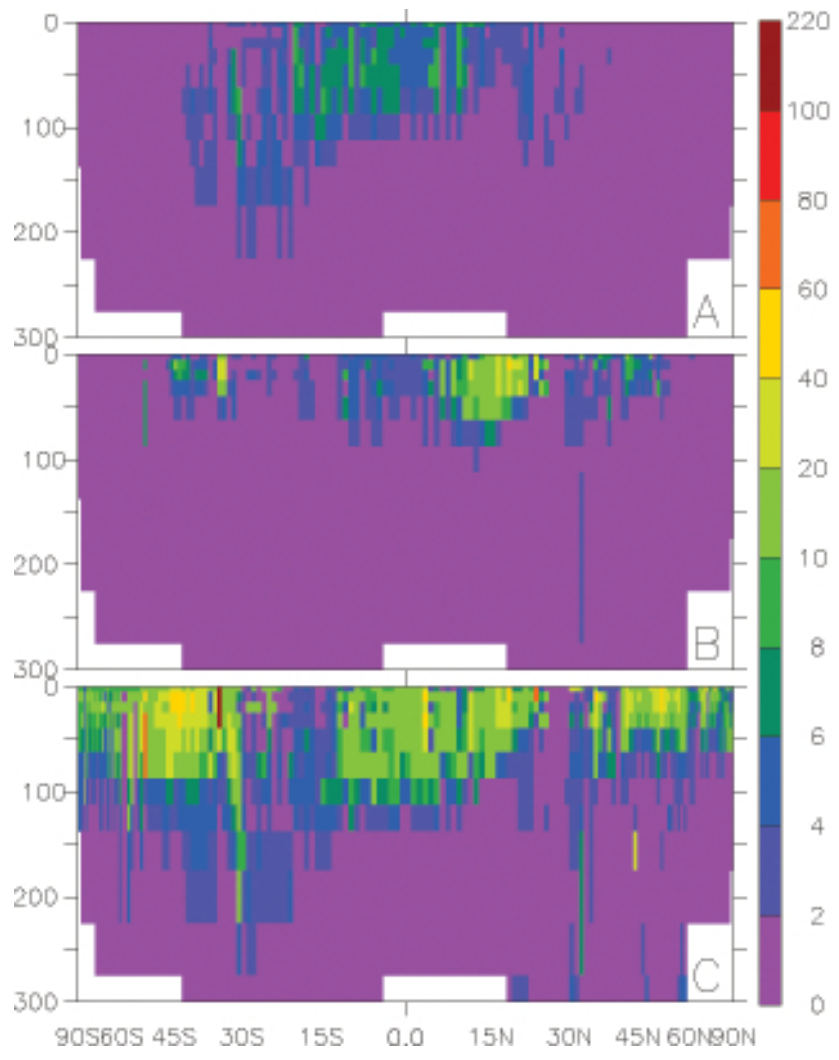

Figure 6. Zonal and time-averaged biomass $\left[\mu \mathrm{g} \mathrm{Cl}^{-1}\right]$ of (A) Prochlorococcus, (B) Synechococcus, (C) picoeukaryotes. Data have been filled by latitudinal interpolation of up to $22^{\circ}$.

the detection limit of standard flow cytometers (Dusenberry and Frankel, 1994).

It has been repeatedly shown that Prochlorococcus and Synechococcus increase in cell size with depth up to $\sim 150 \mathrm{~m}$. In contrast, previously published results for picoeukaryotes showed little variation in size as a function of depth (Li et al., 1993; DuRand et al., 2001; Grob et al., 2007). We compared the increase in size for the three groups at two locations. At BATS (Bermuda Atlantic Timeseries Station; which includes the data of DuRand et al., 2001), we also find an increase in cell size of Prochlorococcus and Synechococcus but not picoeukaryotes (Fig. 8a). However, in the Western Mediterranean (Almo-1 and -2, Jacquet et al., 2010), we find a similar increase in cell size of Prochlorococcus and Synechococcus, but a much larger increase of picoeukaryotes (Fig. 8b). The difference this could make to the global picophytoplankton biomass is large. If we use the standard conversion factors in the surface and increase these linearly up to a factor 3 below $150 \mathrm{~m}$ depth (blue lines in Fig. 8), then the global biomass becomes $1.32 \mathrm{PgC}(+78 \%)$, or if we only apply this increasing conversion factor to Prochlorococcus and Synechococcus, we estimate a global biomass of $0.93 \mathrm{PgC}$ $(+25 \%)$. Our standard conversion factors are taken from laboratory studies. Conversion factors for heterotrophic bacteria 


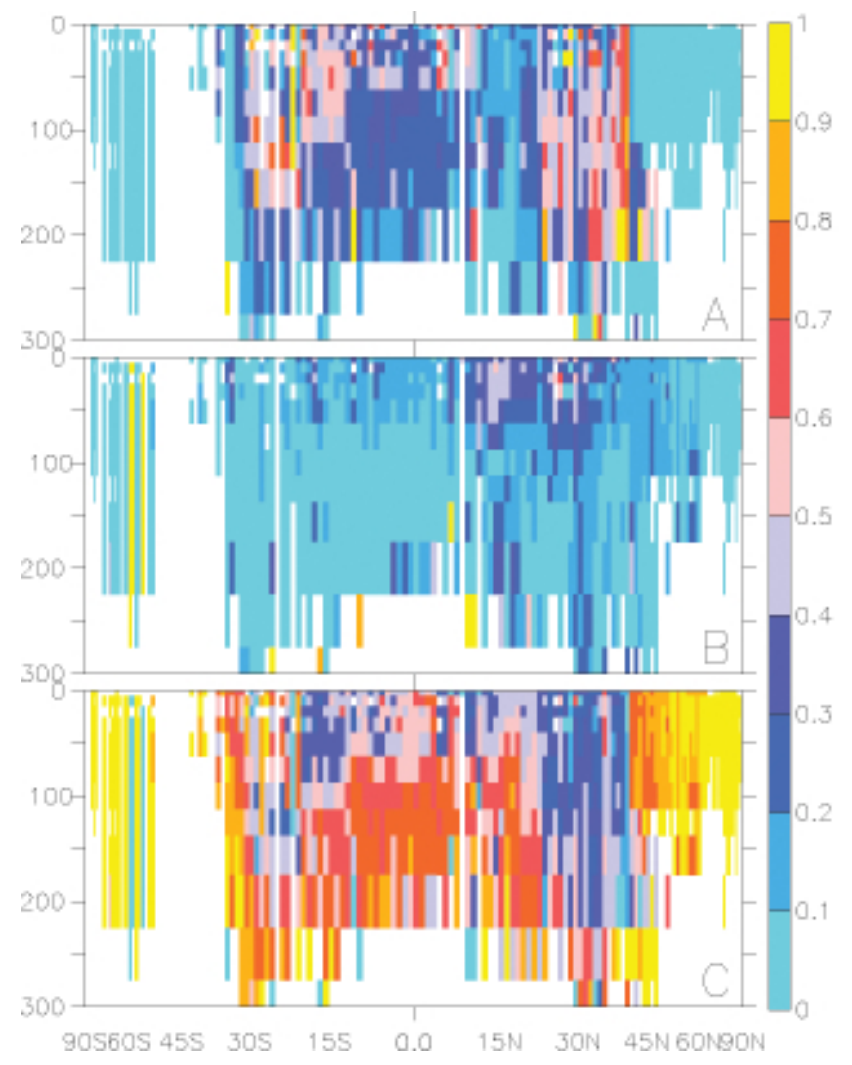

Figure 7. Zonal and time-averaged fraction of total picophytoplankton (A) Prochlorococcus, (B) Synechococcus, (C) picoeukaryotes.

from laboratory studies tend to be higher than from in situ measurements (Buitenhuis et al., 2012a). Indeed, even if we do not account for an increase of cell size with depth, the laboratory conversion factors lead to a higher biomass estimate than the indirect conversion factors. Other sources of variability are seasonal variations of cell size (DuRand et al., 2001) of all picophytoplankton and increasing cell size of Prochlorococcus with latitude towards the equator (Viviani et al., 2011). Thus, it is clear that there is considerable uncertainty in the conversion factors, but in the absence of general trends for the cell size variability of each group under all conditions, our estimate of $0.74 \mathrm{Pg} \mathrm{C}$ represents our best estimate of the global picophytoplankton biomass.

Le Quéré et al. (2005) estimated that the global picophytoplankton biomass, including nitrogen fixers, is $0.28 \mathrm{Pg} \mathrm{C}$. Our estimate, excluding nitrogen fixers, is considerably higher at $0.74 \mathrm{PgC}$, and even our estimate using the indirect conversion factors is still almost double at $0.53 \mathrm{Pg} \mathrm{C}$. Le Quéré et al. (2005) suggested that a third of global phytoplankton biomass is in the pico size class. Therefore, a 2-3fold difference in the estimated picophytoplankton biomass would not only be important for calculating the relative contribution that picophytoplankton make to the phytoplankton
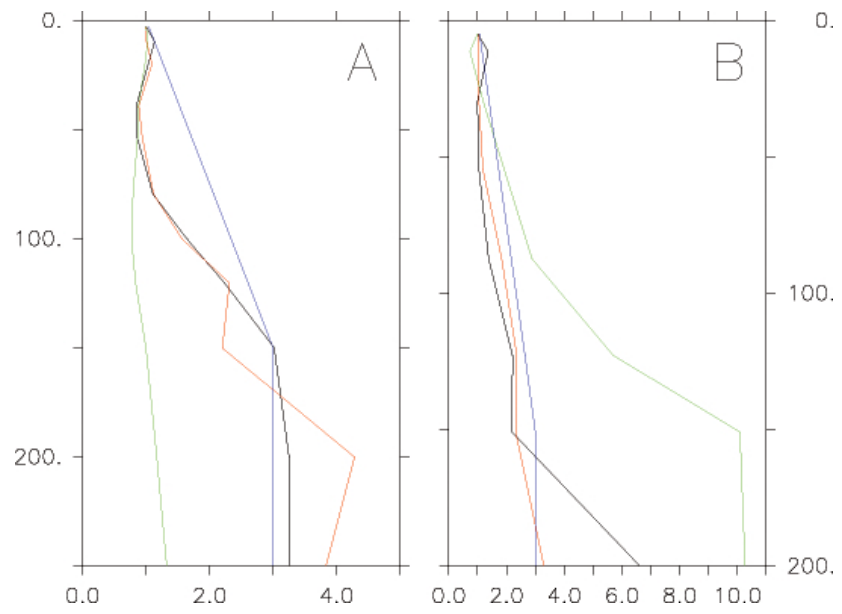

Figure 8. Cell size as a function of depth, normalised to cell size at the surface, (black) Prochlorococcus, (red) Synechococcus, (green) picoeukaryotes, (blue) exploratory conversion factor that increases up to a factor 3 below $150 \mathrm{~m}$ depth. (A) At BATS, (B) in the Western Mediterranean (Almo-1 and -2).

but also for calculating the total biomass of phytoplankton as the base of the ocean ecosystem.

For picoeukaryotes, the definition of the size range to be included is a major source of ambiguity. Whether phytoplankton between 2 and $3 \mu \mathrm{m}$ diameter are included as picophytoplankton not only affects the abundance of the picoeukaryotes, but also which conversion factor is applicable. Here, we have included measurements of cells up to $3 \mu \mathrm{m}$ diameter in the carbon conversion factor (Table 2). As a consequence, our conclusion that picoeukaryotes constitute $69 \%$ of global picophytoplankton biomass critically depends on the definition of the size cut-off.

In summary, thanks to the routine use of flow cytometry for measurement of picophytoplankton abundance, we obtained a global dataset with reasonable coverage. The two main issues that deserve future attention are better resolution of cell sizes and better sampling coverage in the Southern Hemisphere.

Acknowledgements. We thank Claude Belzile, Jacques Neveux and Geneviève Tremblay for their comments on a draft manuscript, the EU (CarboChange, contract 264879) for financial support to ETB, and the Networks of Centres of Excellence of CanadaArcticNet for financial support to MG. We thank the reviewers for their helpful comments.

Edited by: S. Pesant 


\section{References}

Alvain, S., Moulin, C., Dandonneau, Y., and Breon, F. M.: Remote sensing of phytoplankton groups in case 1 waters from global SeaWiFS imagery, Deep-Sea Res. Pt. I, 52, 1989-2004, 2005.

Bertilsson, S., Berglund, O., Karl, D. M., and Chisholm, S. W.: Elemental composition of marine Prochlorococcus and Synechococcus: Implications for the ecological stoichiometry of the sea, Limnol. Oceanogr., 48, 1721-1731, 2003.

Binder, B. J., Chisholm, S. W., Olson, R. J., Frankel, S. L., and Worden, A. Z.: Dynamics of picophytoplankton, ultraphytoplankton and bacteria in the central equatorial Pacific, Deep-Sea Res. Pt. II, 43, 907-931, 1996.

Blanchot, J. and Rodier, M.: Picophytoplankton abundance and biomass in the western tropical Pacific Ocean during the 1992 El Nino year: Results from flow cytometry, Deep-Sea Res. Pt. I, 43, 877-895, 1996.

Blanchot, J., Andre, J. M., Navarette, C., Neveux, J., and Radenac, M. H.: Picophytoplankton in the equatorial Pacific: vertical distributions in the warm pool and in the high nutrient low chlorophyll conditions, Deep-Sea Res. Pt. I, 48, 297-314, 2001.

Bouman, H. A., Ulloa, O., Barlow, R., Li, W. K. W., Platt, T., Zwirglmaier, K., Scanlan, D. J., and Sathyendranath, S.: Watercolumn stratification governs the community structure of subtropical marine picophytoplankton, Environmental Microbiology Reports, 3, 473-482, 2011.

Buck, K. R., Chavez, F. P., and Campbell, L.: Basin-wide distributions of living carbon components and the inverted trophic pyramid of the central gyre of the North Atlantic Ocean, summer 1993, Aquat. Microb. Ecol., 10, 283-298, 1996.

Buitenhuis, E. T., Li, W. K. W., Lomas, M. W., Karl, D. M., Landry, M. R., and Jacquet, S.: Bacterial biomass distribution in the global ocean, Earth Syst. Sci. Data Discuss., 5, 301-315, doi:10.5194/essdd-5-301-2012, 2012a.

Buitenhuis, E. T., Vogt, M., Bednarsek, N., Doney, S. C., Leblanc, K., Le Quéré, C., Luo, Y.-W., Moriarty, R., O’Brien, C., O’Brien, T., Peloquin, J., and Schiebel, R.: MAREDAT: Towards a World Ocean Atlas of MARine Ecosystem DATa, Earth Syst. Sci. Data Discuss., in preparation, $2012 \mathrm{~b}$.

Cailliau, C., Claustre, H., Vidussi, F., Marie, D., and Vaulot, D.: Carbon biomass, and gross growth rates as estimated from C-14 pigment labelling, during photoacclimation in Prochlorococcus CCMP 1378, Mar. Ecol.-Prog. Ser., 145, 209-221, 1996.

Campbell, L., Nolla, H. A., and Vaulot, D.: The Importance of Prochlorococcus to Community Structure in the Central North Pacific-Ocean, Limnol. Oceanogr., 39, 954-961, 1994.

Campbell, L., Liu, H. B., Nolla, H. A., and Vaulot, D.: Annual variability of phytoplankton and bacteria in the subtropical North Pacific Ocean at Station ALOHA during the 1991-1994 ENSO event, Deep-Sea Res. Pt. I, 44, 167-192, 1997.

Campbell, L., Landry, M. R., Constantinou, J., Nolla, H. A., Brown, S. L., Liu, H., and Caron, D. A.: Response of microbial community structure to environmental forcing in the Arabian Sea, DeepSea Res. Pt. II, 45, 2301-2325, 1998.

Campbell, L., Carpenter, E. J., Montoya, J. P., Kustka, A. B., and Capone, D. G.: Picoplankton community structure within and outside a Trichodesmium bloom in the southwestern Pacific Ocean, Vie et Milieu, 55, 185-195, 2005.
Cavender-Bares, K. K., Rinaldo, A., and Chisholm, S. W.: Microbial size spectra from natural and nutrient enriched ecosystems, Limnol. Oceanogr., 46, 778-789, 2001.

Claustre, H., Bricaud, A., Babin, M., Bruyant, F., Guillou, L., Le Gall, F., Marie, D., and Partensky, F.: Diel variations in Prochlorococcus optical properties, Limnol. Oceanogr., 47, 1637-1647, 2002.

DuRand, M. D. and Olson, R. J.: Contributions of phytoplankton light scattering and cell concentration changes to diel variations in beam attenuation in the equatorial Pacific from flow cytometric measurements of pico-, ultra- and nanoplankton, Deep-Sea Res. Pt. II, 43, 891-906, 1996.

DuRand, M. D., Olson, R. J., and Chisholm, S. W.: Phytoplankton population dynamics at the Bermuda Atlantic Time-series station in the Sargasso Sea, Deep-Sea Res. Pt. II, 48, 1983-2003, 2001.

DuRand, M. D., Green, R. E., Sosik, H. M., and Olson, R. J.: Diel variations in optical properties of Micromonas pusilla (Prasinophyceae), J. Phycol., 38, 1132-1142, 2002.

Dusenberry, J. A. and Frankel, S. L.: Increasing the Sensitivity of a Facscan Flow Cytometer to Study Oceanic Picoplankton, Limnol. Oceanogr., 39, 206-209, 1994.

Echevarría, F., Zabala, L., Corzo, A., Navarro, G., Prieto, L., and Macias, D.: Spatial distribution of autotrophic picoplankton in relation to physical forcings: the Gulf of Cadiz, Strait of Gibraltar and Alboran Sea case study, J. Plankton Res., 31, 1339-1351, 2009.

Fu, F.-X., Warner, M. E., Zhang, Y., Feng, Y., and Hutchins, D. A.: Effects of increased temperature and $\mathrm{CO}_{2}$ on photosynthesis, growth, and elemental ratios in marine Synechococcus and Prochlorococcus (Cyanobacteria), J. Phycol., 43, 485-496, 2007.

Garcia, C. M., Jimenez-Gomez, F., Rodriguez, J., Bautista, B., Estrada, M., Garcia Braun, J., Gasol, J. M., Figueiras, F. G., and Guerrero, F.: The size structure and functional composition of ultraplankton and nanoplankton at a frontal station in the Alboran Sea. Working groups 2 and 3 report, Sci. Mar., 58, 43-52, 1994.

Grob, C., Ulloa, O., Claustre, H., Huot, Y., Alarcón, G., and Marie, D.: Contribution of picoplankton to the total particulate organic carbon concentration in the eastern South Pacific, Biogeosciences, 4, 837-852, doi:10.5194/bg-4-837-2007, 2007.

Jacquet, S., Prieur, L., Nival, P., and Vaulot, D.: Structure and variability of the microbial community associated to the Alboran Sea frontal system (Western Mediterranean) in winter, J. Oceanogr., Research and Data, 3, 47-75, 2010.

Johnson, Z. I., Zinser, E. R., Coe, A., McNulty, N. P., Woodward, E. M. S., and Chisholm, S. W.: Niche partitioning among Prochlorococcus ecotypes along ocean-scale environmental gradients, Science, 311, 1737-1740, 2006.

Kana, T. M. and Glibert, P. M.: Effect of Irradiances up to $2000 \mu \mathrm{E} \mathrm{m}^{-2} \mathrm{~s}^{-1}$ on Marine Synechococcus WH7803. 1. Growth, Pigmentation, and Cell Composition, Deep-Sea Res., 34, 479495, 1987.

Landry, M. R., Kirshtein, J., and Constantinou, J.: Abundances and distributions of picoplankton populations in the central equatorial Pacific from $12^{\circ} \mathrm{N}$ to $12^{\circ} \mathrm{S}, 140^{\circ} \mathrm{W}$, Deep-Sea Res. Pt. II, 43, 871-890, 1996.

Le Quéré, C., Harrison, S. P., Prentice, I. C., Buitenhuis, E. T., Aumont, O., Bopp, L., Claustre, H., Da Cunha, L. C., Geider, R., Giraud, X., Klaas, C., Kohfeld, K. E., Legendre, L., Manizza, M., Platt, T., Rivkin, R. B., Sathyendranath, S., Uitz, J., Watson, A. 
J., and Wolf-Gladrow, D.: Ecosystem dynamics based on plankton functional types for global ocean biogeochemistry models, Glob. Change Biol., 11, 2016-2040, 2005.

Li, W. K. W.: Phytoplankton biomass and chlorophyll concentration across the North Atlantic, Sci. Mar., 58, 67-79, 1994.

Li, W. K. W.: Composition of Ultraphytoplankton in the Central North-Atlantic, Mar. Ecol.-Prog. Ser., 122, 1-8, 1995.

Li, W. K. W.: Cytometric diversity in marine ultraphytoplankton, Limnol. Oceanogr., 42, 874-880, 1997.

Li, W. K. W.: Macroecological patterns of phytoplankton in the northwestern North Atlantic Ocean, Nature, 419, 154-157, 2002.

Li, W. K. W.: From cytometry to macroecology: a quarter century quest in microbial oceanography, Aquat. Microb. Ecol., 57, 239$251,2009$.

Li, W. K. W. and Harrison, W. G.: Chlorophyll, bacteria and picophytoplankton in ecological provinces of the North Atlantic, Deep-Sea Res. Pt. II, 48, 2271-2293, 2001.

Li, W. K. W. and Wood, A. M.: Vertical Distribution of NorthAtlantic Ultraphytoplankton - Analysis by Flow-Cytometry and Epifluorescence Microscopy, Deep-Sea Res., 35, 1615-1638, 1988.

Li, W. K. W., Dickie, P. M., Irwin, B. D., and Wood, A. M.: Biomass of Bacteria, Cyanobacteria, Prochlorophytes and Photosynthetic Eukaryotes in the Sargasso Sea, Deep-Sea Res., 39, 501-519, 1992.

Li, W. K. W., Zohary, T., Yacobi, Y. Z., and Wood, A. M.: Ultraphytoplankton in the Eastern Mediterranean-Sea - Towards Deriving Phytoplankton Biomass from Flow Cytometric Measurements of Abundance, Fluorescence and Light Scatter, Mar. Ecol.Prog. Ser., 102, 79-87, 1993.

Li, W. K. W., McLaughlin, F. A., Lovejoy, C., and Carmack, E. C.: Smallest Algae Thrive As the Arctic Ocean Freshens, Science, 326, 539-539, 2009.

Lindell, D. and Post, A. F.: Ultraphytoplankton Succession Is Triggered by Deep Winter Mixing in the Gulf-of-Aqaba (Eilat), RedSea, Limnol. Oceanogr., 40, 1130-1141, 1995.

Liu, H. B., Bidigare, R. R., Laws, E., Landry, M. R., and Campbell, L.: Cell cycle and physiological characteristics of Synechococcus (WH7803) in chemostat culture, Mar. Ecol.-Prog. Ser., 189, 17-25, 1999.

Llewellyn, C. A. and Gibb, S. W.: Intra-class variability in the carbon, pigment and biomineral content of prymnesiophytes and diatoms, Mar. Ecol.-Prog. Ser., 193, 33-44, 2000.

Lomas, M. W., Roberts, N., Lipschultz, F., Krause, J. W., Nelson, D. M., and Bates, N. R.: Biogeochemical responses to late-winter storms in the Sargasso Sea. IV. Rapid succession of major phytoplankton groups, Deep-Sea Res. Pt. I, 56, 892-908, 2009.

Lomas, M. W., Steinberg, D. K., Dickey, T., Carlson, C. A., Nelson, N. B., Condon, R. H., and Bates, N. R.: Increased ocean carbon export in the Sargasso Sea linked to climate variability is countered by its enhanced mesopelagic attenuation, Biogeosciences, 7, 57-70, doi:10.5194/bg-7-57-2010, 2010.

Marie, D., Zhu, F., Balague, V., Ras, J., and Vaulot, D.: Eukaryotic picoplankton communities of the Mediterranean Sea in summer assessed by molecular approaches (DGGE, TTGE, QPCR), FEMS Microb. Ecol., 55, 403-415, 2006.

McManus, G. B. and Dawson, R.: Phytoplankton Pigments in the Deep Chlorophyll Maximum of the Caribbean Sea and the Western Tropical Atlantic-Ocean, Mar. Ecol.-Prog. Ser., 113, 199-
206, 1994.

Montagnes, D. J. S., Berges, J. A., Harrison, P. J., and Taylor, F. J. R.: Estimating Carbon, Nitrogen, Protein, and Chlorophyll-a from Volume in Marine-Phytoplankton, Limnol. Oceanogr., 39, 1044-1060, 1994.

Moran, S. B., Lomas, M. W., Kelly, R. P., Gradinger, R., Iken, K., and Mathis, J. T.: Seasonal succession of net primary productivity, particulate organic carbon export, and autotrophic community composition in the eastern Bering Sea, Deep-Sea Res. Pt. II, 65-70, 84-97, 2012.

Moran, X. A. G., Lopez-Urrutia, A., Calvo-Diaz, A., and Li, W. K. W.: Increasing importance of small phytoplankton in a warmer ocean, Glob. Change Biol., 16, 1137-1144, 2010.

Neveux, J., Vaulot, D., Courties, C., and Fukai, E.: Green Photosynthetic Bacteria Associated with the Deep Chlorophyll Maximum of the Sargasso Sea, CR. Acad. Sci. III-Vie., 308, 9-14, 1989.

Neveux, J., Lantoine, F., Vaulot, D., Marie, D., and Blanchot, J.: Phycoerythrins in the southern tropical and equatorial Pacific Ocean: Evidence for new cyanobacterial types, J. Geophys. Res.Oceans, 104, 3311-3321, 1999.

Olson, R. J., Chisholm, S. W., Zettler, E. R., Altabet, M. A., and Dusenberry, J. A.: Spatial and Temporal Distributions of Prochlorophyte Picoplankton in the North-Atlantic Ocean, DeepSea Res., 37, 1033-1051, 1990.

Partensky, F., Blanchot, J., Lantoine, F., Neveux, J., and Marie, D.: Vertical structure of picophytoplankton at different trophic sites of the tropical northeastern Atlantic Ocean, Deep-Sea Res. Pt. I, 43, 1191-1213, 1996.

Raven, J. A.: The twelfth Tansley Lecture. Small is beautiful: the picophytoplankton, Funct. Ecol., 12, 503-513, 1998.

Sherr, E. B., Sherr, B. F., and Wheeler, P. A.: Distribution of coccoid cyanobacteria and small eukaryotic phytoplankton in the upwelling ecosystem off the Oregon coast during 2001 and 2002, Deep-Sea Res. Pt. II, 52, 317-330, 2005.

Shimada, A., Hasegawa, T., Umeda, I., Kadoya, N., and Maruyama, T.: Spatial Mesoscale Patterns of West Pacific Picophytoplankton as Analyzed by Flow-Cytometry - Their Contribution to Subsurface Chlorophyll Maxima, Mar. Biol., 115, 209-215, 1993.

Shimada, A., Nishijima, M., and Maruyama, T.: Seasonal appearance of Prochlorococcus in Suruga Bay, Japan in 1992-1993, J. Oceanogr., 51, 289-300, 1995.

Sieburth, J. M., Smetacek, V., and Lenz, J.: Pelagic Ecosystem Structure - Heterotrophic Compartments of Plankton and Their Relationship to Plankton Size Fractions - Comment, Limnol. Oceanogr., 23, 1256-1263, 1978.

Simon, N., Barlow, R. G., Marie, D., Partensky, F., and Vaulot, D.: Characterization of Oceanic Photosynthetic Picoeukaryotes by Flow-Cytometry, J. Phycol., 30, 922-935, 1994.

Takahashi, M. and Hori, T.: Abundance of Picophytoplankton in the Subsurface Chlorophyll Maximum Layer in Sub-Tropical and Tropical Waters, Mar. Biol., 79, 177-186, 1984.

Tremblay, G., Belzile, C., Gosselin, M., Poulin, M., Roy, S., and Tremblay, J.-E.: Late summer phytoplankton distribution along a $3500 \mathrm{~km}$ transect in Canadian Arctic waters: strong numerical dominance by picoeukaryotes, Aquat. Microb. Ecol., 54, 55-70, 2009.

Vaulot, D., Partensky, F., Neveux, J., Mantoura, R. F. C., and Llewellyn, C. A.: Winter Presence of Prochlorophytes in Surface Waters of the Northwestern Mediterranean-Sea, Limnol. 
Oceanogr., 35, 1156-1164, 1990.

Vaulot, D., Eikrem, W., Viprey, M., and Moreau, H.: The diversity of small eukaryotic phytoplankton $(<=3 \mu \mathrm{m})$ in marine ecosystems, FEMS Microb. Rev., 32, 795-820, 2008.

Veldhuis, M. J. W. and Kraay, G. W.: Vertical-Distribution and Pigment Composition of a Picoplanktonic Prochlorophyte in the Subtropical North-Atlantic - a Combined Study of HplcAnalysis of Pigments and Flow-Cytometry, Mar. Ecol.-Prog. Ser., 68, 121-127, 1990.

Veldhuis, M. J. W. and Kraay, G. W.: Cell Abundance and Fluorescence of Picoplankton in Relation to Growth Irradiance and Nitrogen Availability in the Red-Sea, Neth. J. Sea Res., 31, 135145, 1993.

Veldhuis, M. J. W., Kraay, G. W., and Gieskes, W. W. C.: Growth and Fluorescence Characteristics of Ultraplankton on a North South Transect in the Eastern North-Atlantic, Deep-Sea Res. Pt. II, 40, 609-626, 1993.

Veldhuis, M. J. W., Kraay, G. W., VanBleijswijk, J. D. L., and Baars, M. A.: Seasonal and spatial variability in phytoplankton biomass, productivity and growth in the northwestern Indian Ocean: The southwest and northeast monsoon, 1992-1993, Deep-Sea Res. Pt. I, 44, 425-449, 1997.
Verity, P. G., Robertson, C. Y., Tronzo, C. R., Andrews, M. G., Nelson, J. R., and Sieracki, M. E.: Relationships between CellVolume and the Carbon and Nitrogen-Content of Marine Photosynthetic Nanoplankton, Limnol. Oceanogr., 37, 1434-1446, 1992.

Viviani, D. A., Bjoerkman, K. M., Karl, D. M., and Church, M. J.: Plankton metabolism in surface waters of the tropical and subtropical Pacific Ocean, Aquat. Microb. Ecol., 62, 1-12, 2011.

Worden, A. Z., Nolan, J. K., and Palenik, B.: Assessing the dynamics and ecology of marine picophytoplankton: The importance of the eukaryotic component, Limnol. Oceanogr., 49, 168-179, 2004.

Yacobi, Y. Z., Zohary, T., Kress, N., Hecht, A., Robarts, R. D., Waiser, M., and Wood, A. M.: Chlorophyll Distribution Throughout the Southeastern Mediterranean in Relation to the Physical Structure of the Water Mass, J. Marine Syst., 6, 179-190, 1995. 